\title{
TEACHING HISTORY OF ARCHITECTURE - MOVING FROM A KNOWLEDGE TRANSFER TO A MULTI-PARTICIPATIVE METHODOLOGY BASED ON IT TOOLS
}

\author{
Guido Cimadomo \\ Escuela Tecnics Superior de Arquitectura \\ Universidad de Málaga \\ (University of Malaga), Spain \\ cimadomo@uma.es
}

\begin{abstract}
The changes that the European Higher Education Area (EHEA) framework obliged the School of Architecture of Malaga, University of Malaga. to make to its "History of Architecture" course are discussed in this paper. It was taken up as an opportunity to modify the whole course, introducing creative teaching and "imaginative activities" to put the students at the centre of the learning experience and giving them part control over the course. IT technologies such as Pinterest were used to create a friendly visual learning environment to offer richer learning experiences and positive effects on the students. Time dedicated to the presentation of theoretical content in the course was reduced by half and the program was redefined from the chronology of the previous program to a reading of the use of the classical orders throughout history. This change generated interest, curiosity and a greater understanding of the relationships between different styles which use the same elements. The implementation of several activities such as problem solving exercises, complementary readings and video helped to focus the course on a student-centred learning environment, was valued positively by the students.
\end{abstract}

Keywords

Cooperative learning, participation, EHEA, history of architecture, teaching creatively, problem solving, architecture.

\section{Introduction}

A new degree in Architecture aligned with the European Higher Education Area (EHEA) and the 1999 Bologna Declaration started at the University of Malaga during the academic year of 2010-11. The main aim of the EHEA was the creation of a European space for higher education that would permit compatibility, coherence and a wider mobility across Europe (Fernández Díaz, Carballo Santaolalla, \& Galán González, 2010). Among the main modifications that should 
be highlighted is a switch from a teacher-focused transmission of knowledge to a student-centred approach to learning and the introduction of the European Credit Transfer System (ECTS). The transfer system is no longer only measured by the number of teaching hours received by the student but also the sum of hours dedicated to study and personal work for readings, seminars and presentations (Martín Martín \& Wolff, 2011; Trigwell, Prosser \& Waterhouse, 1999). This means great change in the framework of higher education teaching in Europe requiring re-organisation of spaces, times and resources where students can develop a self-directed methodology (Palomares Ruiz, 2011).

Moving from a knowledge-teaching to a student-oriented learning approach needs a careful strategy. A switch to a "learn to learn" process where students are expected to do more than just "know" should help prepare them to adapt to changing and demanding situations through transversal skills such as "know how" and "know how to be." The emergence of the EHEA could therefore be considered as an opportunity to update teaching programs through new methodologies.

Numerous papers have been published on the ideas behind the EHEA and its earlier implementations throughout Europe although few specific works have been concerned with courses in Architecture and their adaptation to the new framework. For example, Álvarez et al. (2010) dealt with the adaptation of Physics subjects while, also at University of Alicante, Spain, Mora García, Céspedes López, Rodríguez Valenzuela and Jiménez Delgado (2012) analysed the workload in the Technical Architecture degree course. Further to this, Orcun Sakarya et al. (2011) reported the experience of the Department of Interior Design at Çancaya University, Turkey. While the research on key issues related to teaching such as those on creative models (Craft \& Jeffrey, 2008; Jeffrey \& Craft, 2004; McWilliam, 2009) and co-operative learning (Gonzalez, 2014; Voorhees 2001) are widely developed, the research on theory-based courses in architecture is still reduced to individual attempts (Salama, 2010; Teal 2011) and do not address the EHEA framework.

The aim of this paper is to present a case study where a degree in Architecture at the University of Malaga is in the process of being redesigned and redefined according to the educational criteria and guidelines of the EHEA. It will specifically consider the modifications made to the pedagogical structure of the course, History of Architecture II. The previous model of the course is presented and the issues encountered in adapting it to the EHEA framework are discussed. The experience of the course during the academic years of 2012-13 and 2013-14 and the experience of the first students to learn through the new approach is also presented. The results of this experience are analysed with the help of a feedback survey held in December 2013 to determine if the changes made represented a better model of learning. The survey showed that considerable improvements were achieved and that the solutions adopted, namely, Information Technologies, cloud-based applications and the use of creative teaching, offered a possible answer to the challenge that the EHEA framework represents. 


\section{Course structure prior to the EHEA implementation}

History and Theory of Architecture III was taught in the first semester of the third year of the Master of Science in Architecture, for a total of 60 hours divided into two-hour classes twice a week. It was premised on the idea that Nil difficile volenti (see Figure 1).

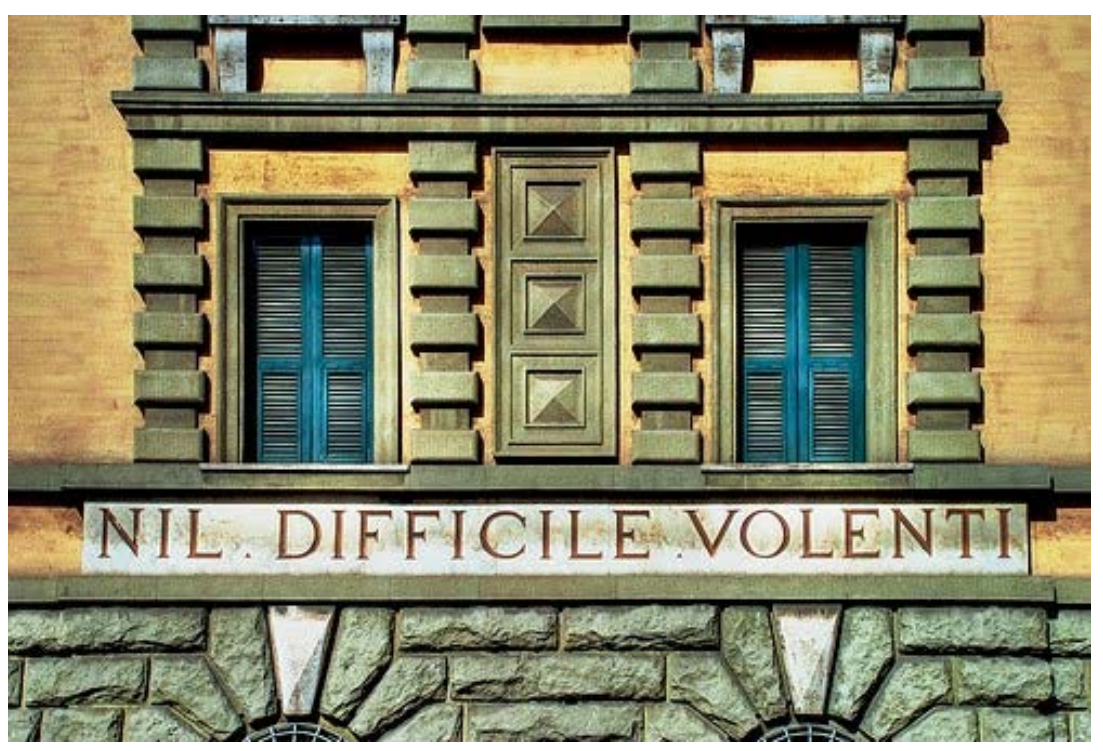

Figure 1. "Nil difficile volenti" (Nothing (is) impossible to the one who wants it) is the first image presented during the History of Architecture course.

The course dealt with the chronological evolution of architecture from Ancient Greece to the Industrial Revolution linked with the historical and artistic changes in these periods. This followed the common practice of many Schools of Architecture in Spain and throughout Europe. It was a very intensive program taught over fifteen weeks. It was delivered mostly through lectures focusing on the most significant architects and works of history, their evolution and specific relevance, and the direct relations existing between them. It was a teachingoriented course where knowledge was transmitted through lectures according to the pedagogical models common before the 1999 Bologna Declaration.

Secondary competencies, which were to be developed by the students and related with the "know how" and "know how to be" were realised in small groups outside the course timetable. These typically dealt with such tasks as analysing and drawing the façades of buildings along the Guadalmedina River (see Figure 2) or identifying and analysing industrial heritage buildings in Malaga. Students presented the outcomes of these tasks at the end of the semester in small seminars that concluded the course. As these activities were held off-campus, they received restricted supervision by the professor hence the improvements the students obtained during their development could not be properly evaluated. 


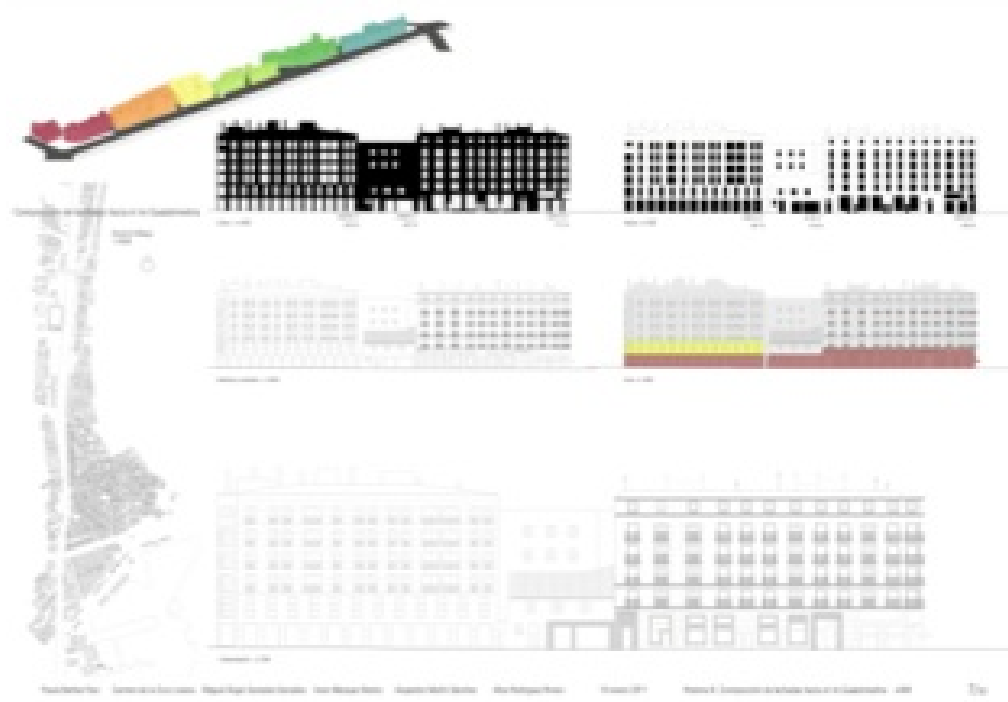

Figure 2. Guadalmedina field work during the 2010-11 academic year (P.

Benítez, C. de la Cruz, M.A. González, I. Márquez, A. Martín, A. Romero).

The “Campus Virtual” interface, a Moodle-based e-learning application offered by the University to support the teaching experience was used mostly for announcements related to course management and news related to architecture in general. For each lecture, a summary was made available to download marking a starting point for the personal learning process. It was considered a valuable support for students who could not attend lectures and a guide to begin the learning process through the bibliographic references provided.

Within this environment, students carried an excessive time/work load with all core courses demanding the same dedication by the student. Students would attend lectures but if discussions and questions about the content did not arise, they did not have the opportunity to have a better understanding of the themes. Typically, dialogue between a professor and a student was hard to generate.

Students tended to concentrate their study time in the few days before the exam where they were required to recollect images of the buildings and important details. Mistakes, confusion and use of poor internet resources, together with inadequate study time produced a rote or mnemonic approach to study with obvious limitations in the critical capacity, analytical comprehension and skills of the students at a midpoint in their professional training.

\section{EHEA Methodology and Learning Process}

During the 2012-13 academic year, the EHEA-compliant History and Theory of Architecture III course was renamed to Historia de la Arquitectura II. The total amount of time now available for the course was reduced to six ECTS meaning that the time dedicated to the presentation of theoretical content via lecture was halved. Two two-hour lectures were replaced with one lecture per week and weekly small-group class of one and a half hours' duration. 
The program was changed from a chronological presentation of architectural evolution to a reading of the use of classical orders throughout history. An attempt to link a concrete architectural language to different historical periods was thought to help students' thinking about their deeper significance and proper use. Ancient Greece, Imperial Rome, Renaissance, Enlightenment and Twentieth Century Totalitarianism became the core elements to be taught. If each step through history was to be recognised and understood by the students, then new teaching methodologies had to be found. As the EHEA framework specifies replacing teacher-centered learning processes with learning models centered on students, their deeper involvement in the preparation of lectures was considered a good model to investigate.

To fulfill the objectives of the new framework while attempting to make the course more dynamic and to create a more positive learning environment, several changes were made from the 2012-13 course. A focus on "using imaginative approaches to make learning more interesting and effective" (Jeffrey \& Craft, 2004, p. 77) was adopted and efforts to generate interest and curiosity were made (Rathod, 2009). These approaches included: (i) using hands-on activities; (ii) creating Pinterest boards; (iii) immersing through video; (iv) using student presentations; (v) engaging with theory; and (vi) problem-solving: personalising the past.

\section{Using hands-on activities}

To break with the tradition set by the previous History of Architecture course and to give the students the idea that something different will happen, the 2012-13 classes started with hands-on activities. Canon's Creative Park was selected allowing students to assemble paper parts to make three-dimensional models including the Parthenon, the Coliseum (Colosseum) and the Cathedral of Florence (Il Duomo di Firenze) (see Figure 3). This package also gives the opportunity to explore the different elements of these buildings. As this took place in the first classes of the course, it served to test students' prior knowledge.

This activity also allowed students to interact with other members of the class thus fostering active learning, promoting collaboration, and generating connections between teachers and students. It is important to note that cooperative learning such as this is a successful teaching strategy that will not only to promote student learning and academic achievement but also develop students' social skills (Rinkevich, 2011). 


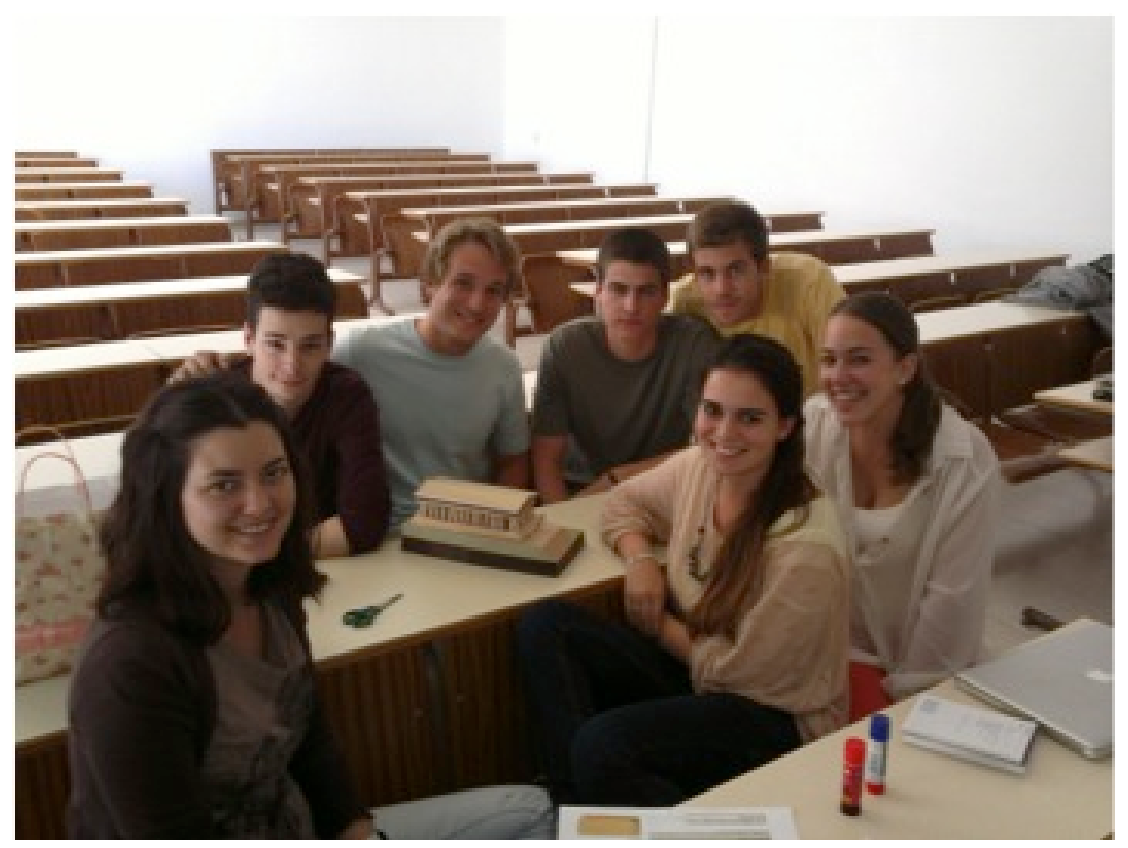

Figure 3. Students showing the result of their classwork: a paper three-dimensional model of the Parthenon.

\section{Creating Pinterest boards}

A technological strategy was designed to give the students more control of the content to be studied. Each week, small groups of students were required to produce images from a list of monuments given by the teacher and upload them to a shared Pinterest ${ }^{1}$ account. Pinterest may be a lesser-known tool but with great potential for students (Ramos, 2013). The compiled images are then presented by the teacher in the following lecture in a quasi passing back-and-forth of control of the course. In this way, the students who undertook this task with the cooperation and supervision of the instructor acquired basic knowledge of well-known monuments.

The second effect is that the task of recollecting images and building plans to be studied is visited continuously during the course, not just at the end of it, with great benefits for students' time and study management. This collaborative and cumulative activity also provided time to generate critiques and reflections on the use of the web, the strengths and weaknesses related with repositories of architectural contents, all facilitated by the use of friendly and common tools. At the end of the year, the students are required to share a portfolio of images. During the semester, the Pinterest images are used as a source for problemsolving activities. The student survey reported later in this paper indicates the success of this strategy in assisting students' learning and enhancing their engagement.

\footnotetext{
${ }^{1}$ See https://www.pinterest.com
} 


\section{Immersing through video}

Hudnut (1957) suggested that students have to experience buildings conceptually, that is, through a holistic idea of them, in order to have a firm idea of them in their minds. Videos of significant buildings, recorded during several trips by the professor, were edited into short clips of about three minutes to encourage this process of immersion. These videos were used as preliminary introductions to buildings before starting to investigate them in detail. Images are used extensively in architectural courses most commonly to identify and describe buildings through photographs and plans (Borden, 2007; Wilson, 2005). Architecture has to be "constructed" through many different images to be fully understood, or as in this course, with the help of videos.

\section{Using student presentations}

The previously-discussed concept of passing control to students is also encouraged through individual/group presentations during the small-group classes. They reported on themes presented during the lectures and were often, for example, asked to present comparisons between different buildings or architectural styles in order to show the main aspects of each. A constant requirement was to be creative and to not repeat what had been presented during the lecture. This also encouraged new skills and competencies including the need to think creatively about the themes studied and to determine how knowledge of past History informs contemporary approaches to design (see Figure 4).

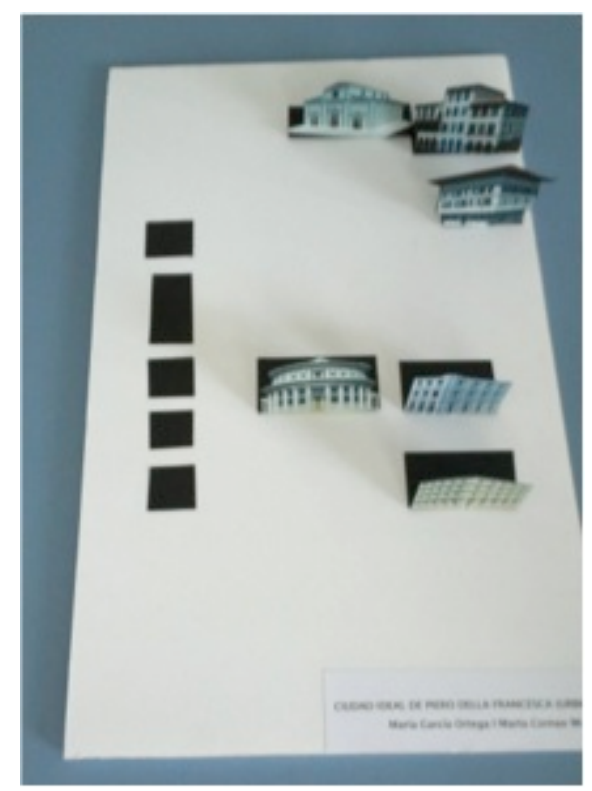

Figure 4. Model reconstruction of the Ideal City painting, Baltimore. (M. Córnax Martín and M. García Ortega). 


\section{Engaging with theory}

To generate a parallel and complementary perspective of the contents of the course, translations of selected texts by the Italian art critic and historian, Cesare Brandi (1906-1988) were offered through the "Campus Virtual” platform. These texts, never fully translated to Spanish, were specifically selected and adapted for this course, as fresh and impressive descriptions explicating the inner relevance of several masterpieces of the past. In several cases, students were asked to read the translated texts and present short abstracts in order to foster their capacity to capture the essence of the buildings presented. It is also considered an exercise to promote the transversal capacities of students.

\section{Problem-solving: personalising the past}

A problem-solving activity was added to the 2013-14 course. As a trial of this approach, students were asked to design the façade of a personal Renaissance church. They were free to choose the typology and to incorporate elements of other buildings already studied (accessible through the shared Pinterest board). They were asked to justify their decisions and to detail the problems that arose and how they were resolved. This exercise was developed as a way to encourage students to reflect on the construction processes available in the 15th Century and to be aware of the compositional elements of a church (see Figure 5).

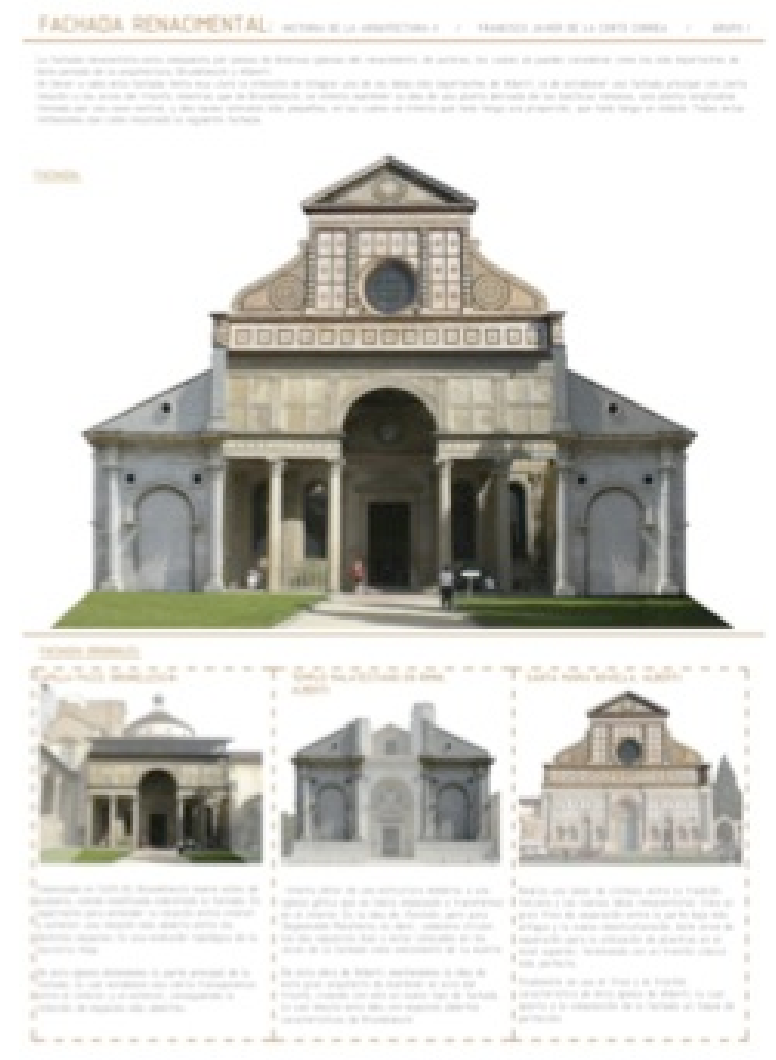

Figure 5. Creation of a Renaissance façade starting from elective elements. (F. J. de la Corte Correa). 
It can thus be seen that a fundamental change has been implemented in the structure of the course, aiming to transform students from passive receptors (something common in lecture courses) to active participants by giving them control over the learning process, integrating them in the flow of preparing the material of the classes and expecting them to demonstrate their understanding in multiple ways. Involvement in the organisation of the contents of the course with a passing of responsibility from the teacher to the students was used to develop the three main aspects of learning: to know, to know how, and to know how to be, developed at different levels.

The activities were designed as a whole in accordance with Rinkevich's (2011) advice that all such strategies have to be implemented coherently so as to be seen as part of the course program rather than as isolated activities. A clear indicator of the change in approach and the genuine integration of the activities was the parallel change in assessment. The final evaluation criteria for the course changed as a result, and personal work developed during the course was given a significantly higher weight of the final score (40\%). This is compared with the previous courses where examinations represented $\sim 75 \%$ of the course leaving $\sim 25 \%$ for personally-directed activities.

\section{Findings}

As noted, at the end of the 2013-14 course, a fourteen question survey about the revised course implementation and its effectiveness was developed. Twenty-nine students responded.

Several questions were particularly concerned with the use of Pinterest (see Figure 6). Only 6 students (20.69\%) had used Pinterest (or similar application) before the beginning of the course. Practically all ( $n=27,93.1 \%)$ found it easy to use and, on average, rated it with a score of 7.4 out of 10 for its usefulness in the learning process. Satisfaction with this technology might explain students' reluctance to suggest the use of "other complementary utilities" with the majority responding in the negative ( $n=27,86.21 \%)$.

Confirm this finding, the students also valued the improvement obtained through the use of Pinterest with a 7.1 out of 10 score and the majority would suggest its use in other courses of the degree $(n=18,62.07 \%)$. The other changes made during the course and reported in this paper were accorded positive ratings. For example, the value of the use of immersive video "to help understand the buildings presented" was rated at 8.0 out of 10 . The value of the complementary activities was rated at 7.0 while the presentations made by the students were rated at 7.2. The engagement with theory — through readings — was rated positively at 7.0.

Only four students (13.79\%) had used similar utilities in other courses showing that little has been done to introduce such technologies into teaching. Suggestions made by the students, which should be given serious consideration, included the use of Mindmaps or Google Drive to complement the tools currently used. 


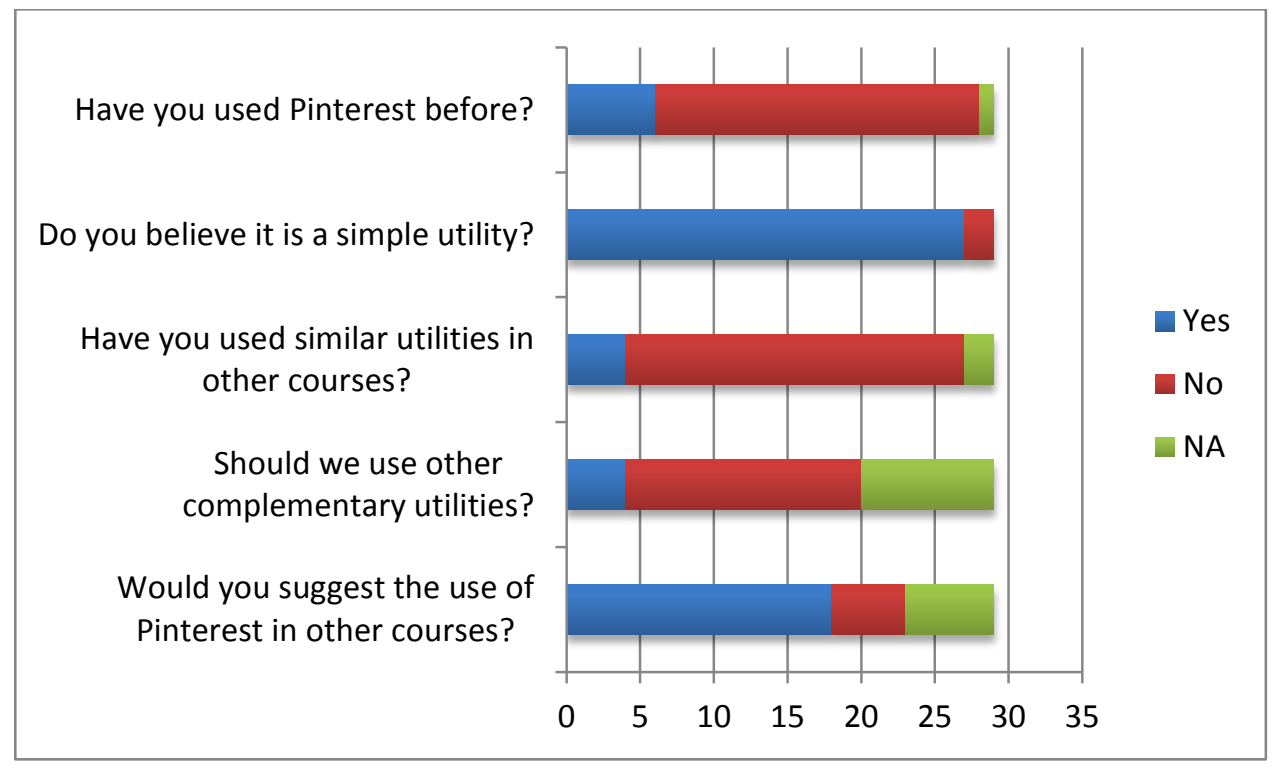

Figure 6. Results of the survey taken in December 2013

\section{Conclusion}

In a School of Architecture, where creativity and design studios are core aspects of the course, the History of Architecture has to be considered not only a theoretical course giving background to the students but also as a further step in defining the profile of future architects. Thinking creatively is the way to find answers to every kind of problem. This is not only accomplished by asking students to be creative but also by teaching creatively. This paper has described a selection of the "imaginative approaches" trialled in accordance with the demands of the EHEA Framework.

Within this revised course, cooperative learning has proven to be a successful teaching strategy, not only to promote student understanding and academic achievement but also to develop students' social skills. Different "imaginative” activities were designed to push the students to be more active when in a theory class. The problem-solving exercises trialled have been recognised as the most effective tool to actively involve students in the course and will be further developed during the next courses with a semester-long practice.

How to stimulate a new dynamic and give students the possibility to define the content of the course, choosing not only the images but the buildings and architects to be discussed, are aspects that could be implemented in future courses. Similarly, new techniques to integrate History of Architecture with other subjects of the degree, such as Building Construction, should also be investigated. 
The extensive use of technology, such as Pinterest or the Moodle platform, offers rich learning experiences which have a positive effect on the students who start "feeling" the buildings instead of just identifying them. With the changes made in this course, students found themselves involved in a visual learning environment, the sphere where they are accustomed to live, making teaching and learning more enjoyable. The strategies used in the course can be considered creative teaching, "as a unique, customised and meaningful exchange of knowledge among all individuals in a learning context” (Rinkevich, 2011, p. 219).

The role of the teacher in this dynamic environment is seen not to make student learn, but to make them see and imagine about form, colour, and light (Hudnut, 1957), in order to obtain effective educational benefits through human transfer processes, kept at the centre of the learning experience (Hicks, 2011). Although imposed by the regulations of the EHEA Framework, the changes made to teaching methods have been surprising and have led to the creation of a new classroom dynamic.

\section{References}

Álvarez, M.L., Gallego Rico, S., Campo, A., Beléndez, A., Belendez, T., Gabriela, P., Dale, R., Hernández, A., Marco, A., Márquez, A., Moreno, J. C., Neipp, C., Ortuño, M., Pérez, M., Rodes, J. J., Rosa, J., Vera, J., Yebra, M., \& Méndez, D. (2010). Physics subjects to complete the basic qualifications and professional attributions for the new engineering and architecture degrees inside the European higher education area. Proceedings of the INTED2010 Conference, Valencia, Spain, March 8-10, 2010. Retrieved from http://rua.ua.es/dspace/bitstream/10045/13619/2/INTED2010_Valencia_Proceedings.p df

Borden, I. (2007). Imaging architecture: The uses of photography in the practice of architectural history. The Journal of Architecture, 12(1), 57-77. doi: 10.1080/13602360701217989

Craft, A., \& Jeffrey, B. (2008). Creativity and performativity in teaching and learning: Tensions, dilemmas, constraints, accommodations and synthesis. British Educational Research Journal, 34(5), 577-584. doi:10.1080/01411920802223842

Fernández Díaz, M. J., Carballo Santaolalla, R., \& Galán González, A. (2010). Faculty attitudes and training needs to respond the new European higher education challenges. Higher Education, 60(1), 101-118. Retrieved from http://www.jstor.org/stable/40784048

Hicks, S. D. (2011). Technology in today's classroom: Are you a tech-savvy teacher? The Clearing House: A Journal of Educational Strategies, Issues and Ideas, 84(5), 188191. doi: 10.1080/00098655.2011.557406

Hudnut, J. (1957). On teaching the history of architecture. Journal of Architectural Education, 12(2), 6-8. 
Jeffrey, B., \& Craft, A. (2004). Teaching creatively and teaching for creativity:

Distinctions and relationships. Educational Studies, 30(1), 77-87. doi:

10.1080/0305569032000159750

Martín Martín, P., \& Wolff, L. B. (2011). The introduction of the new degrees: Suggestions for improvement. Revista De Educación, 356, 703-715. doi: 10.4438/1988-592X-RE-2010-356-120

McWilliam, E. (2009). Teaching for creativity: From sage to guide to meddler. Asia Pacific Journal of Education, 29(3), 281-293. doi: 10.1080/02188790903092787

Mora García, R. T., Céspedes López, M. F., Rodríguez Valenzuela, L., \& Jiménez Delgado, A. (2012). Estimating the workload of a student adapted to the EHEA in the "construction of non-structural elements" technical architecture subject. INTED2012 Proceedings, Valencia. 3601-3612.

Palomares Ruiz, A. (2011). The educational model at university and the use of new methodologies for teaching, learning and assessment. Revista De Educación, 355, 231-232. doi:10.4438/1998-592X-RE-2011-355-038

Ramos, F., \& Fernández-Diego, M. (2013). Using Pinterest in education: A collaborative collection of marketing ads. INTED2013 Proceedings, Valencia, 287-292.

Rathod, M. (2009). Teaching history of architecture. present status and future directions. Architecture - Time, Space \& People, 9(October), 28-33.

Rinkevich, J. L. (2011). Creative teaching: Why it matters and where to begin. The Clearing House: A Journal of Educational Strategies, Issues and Ideas, 84(5), 219223. doi: 10.1080/00098655.2011.575416

Salama, A. M. (2010). Delivering theory courses in architecture: Inquiry-based, active, and experiential learning integrated. International Journal of Architectural Research, $4(2-3), 278-295$.

Teal, R. (2011). Foundational history: An integrated approach to basic design, history, and theory. Journal of Architectural Education, 64(2), 37-45. doi:10.1111/j.1531314X.2010.01125.X

Trigwell, K., Prosser, M., \& Waterhouse, F. (1999). Relations between teachers' approaches to teaching and students' approaches to learning. Higher Education, 37(1), 57-70.

Vázquez, E., Alcover, R. M., Calduch, Á., Richart, B., Chirivella, V., \& Romero, R. (2011). Adaptation of the course "statistics" to the bachelor's degree in computer engineering. 2011 Promotion and Innovation with New Technologies in Engineering Education FINTDI 2011, Teruel.

Voorhees, R. A. (2001). Competency- Based learning models: A necessary future. New Directions for Institutional Research, (110), 5-13.

Wilson, R. (2005). At the limits of genre: Architectural photography and utopic criticism. The Journal of Architecture, 10(3), 265-273. doi:10.1080/13602360500162410

Copyright $@ 2014$ Guido Cimadomo 